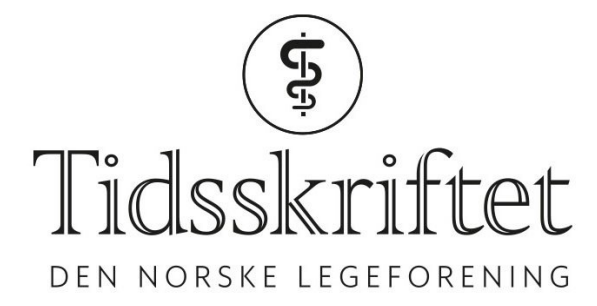

\title{
Begrenset helsehjelp til papirløse migranter gjør noe med oss
}

FRA ANDRE TIDSSKRIFTER

ØYVIND STOPLE SIVERTSEN

Tidsskriftet

Helsepersonell som behandler papirløse immigranter i USA, rapporterer om utbrenthet og tap av moralsk integritet.

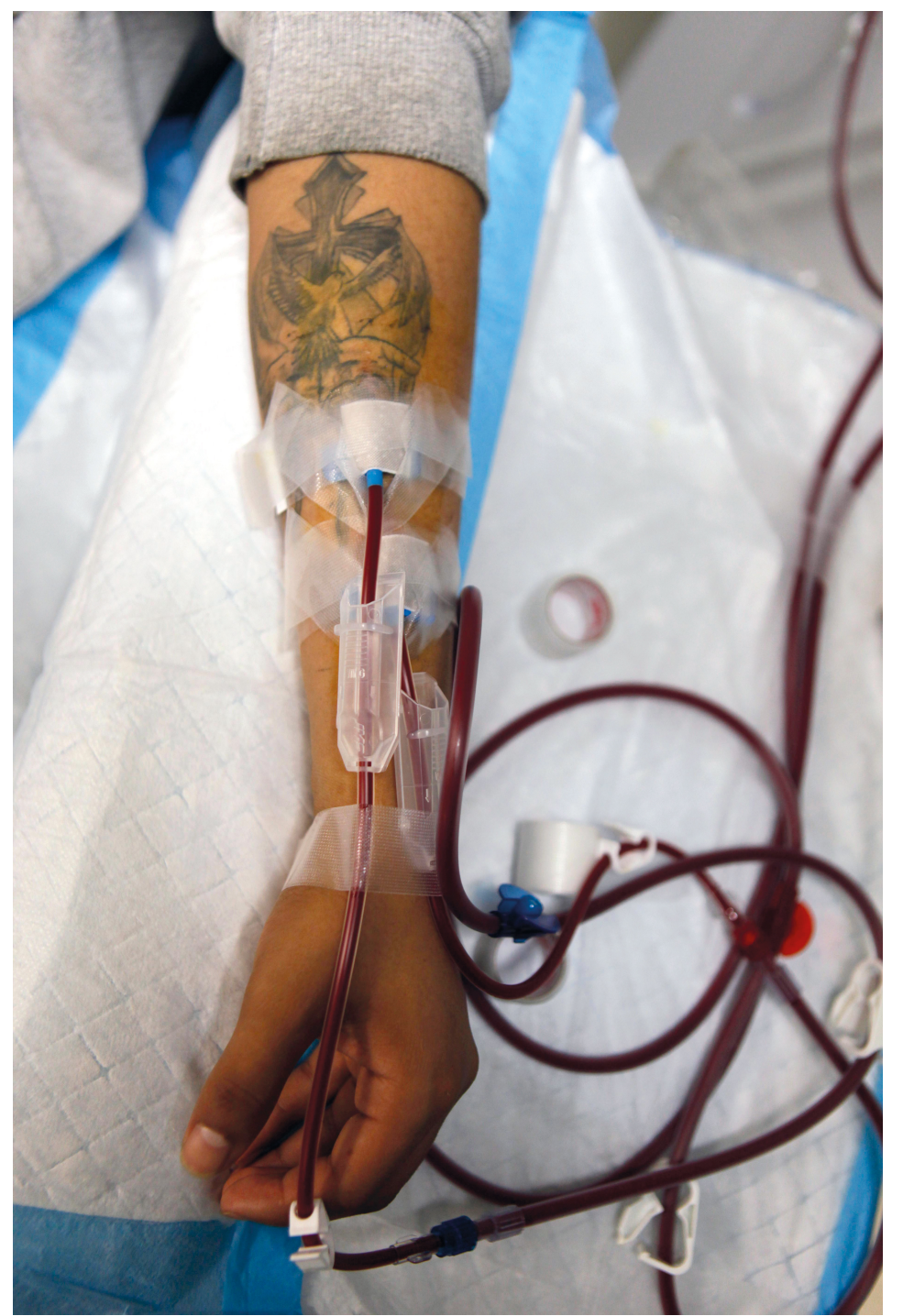

En papirløs immigrant får dialyse ved en klinikk i New York. Foto: Seth Wenig/NTB Scanpix 
Dette kommer frem i en kvalitativ studie av helsepersonell på sykehus i USA som tilbyr dialyse til papirløse immigranter med livstruende nyresvikt (1). Amerikansk lov tillater ikke planlagt dialyse av disse pasientene.

Studien er basert på semistrukturerte intervjuer med 50 klinikere, det vil si leger, sykepleiere og annet helsepersonell, og svarene ble tematisk analysert. De intervjuede klinikerne beskrev at deres moralske integritet ble skadet, og at de ble drevet mot utbrenthet. Årsakene de anga var blant annet at de iakttok unødvendig lidelse og høy dødelighet, de følte at pasientenes tillit til helsevesenet ble skadet og at de fikk større distanse til pasientene.

En opplevelse av at arbeidet førte til at urettferdigheten kunne bestå, skadet behandlernes moralske integritet. De følte at behandlingen kunne bli basert på ikke-medisinske faktorer, at kvantitet gikk foran kvalitet og at systemet måtte manipuleres.

- Dette er viktig forskning som tydelig viser at det å ikke få lov til å yte skikkelig helsehjelp gjør noe med helsearbeiderne og med tilliten til oss, sier Svein Aarseth, som er fastlege i Oslo og leder for Rådet for legeetikk i Legeforeningen.

Han mener at mange norske leger vil kjenne seg igjen i en slik situasjon.

- Som USA har også Norge en streng regulering av tilgang til helsetjenester for papirløse migranter. Denne er fastsatt i Forskrift om rett til helse- og omsorgstjenester til personer uten fast opphold i riket. Slike personer har rett til øyeblikkelig helsehjelp og til helsehjelp som er helt nødvendig og ikke kan vente.

Aarseth sier at de på denne måten blir "svingdørspasienter», idet de kun får helt nødvendig behandling og sendes ut, ofte uten mulighet til å få oppfølging og medisiner. Så blir de igjen akutt hjelpetrengende og innlagt.

- Legeforeningens standpunkt er at alle bør få helsehjelp etter behov, sier Aarseth.

\section{LITTERATUR:}

1. Cervantes L, Richardson S, Raghavan R et al. Clinicians' perspectives on providing emergency-only hemodialysis to undocumented immigrants: A qualitative study. Ann Intern Med 2018; 169: 78-86. [PubMed][CrossRef]

Publisert: 25. februar 2019. Tidsskr Nor Legeforen. DOI: 10.4045/tidsskr.19.0056

(C) Tidsskrift for Den norske legeforening 2020. Lastet ned fra tidsskriftet.no 